\title{
Fenazin sebagai Potensi Antibiotik Baru daripada Streptomyces kebangsaanensis
}

(Fenazin as Potential New Antibiotics from Streptomyces kebangsaanensis)

\author{
JuWairiah Remali, NoraZiah Mohamad ZiN*, Chyan LeONG NG, WAN M. AiZAT \& JOHN J.L Tiong
}

\section{ABSTRAK}

Fenazin merupakan metabolit sekunder yang biasanya disintesis secara semula jadi oleh Pseudomonas dan Streptomyces. Ia merupakan sebatian heterosiklikyang mempunyai sebatian bernitrogen pada struktur teras cecincin. Kajian mengenai antibiotik ini telah bermula seawal abad ke-19 lagi dan ternyata menjadi calon dadah yang berpotensi tinggi dalam dunia perubatan. Sehingga kini, lebih daripada 100 jenis fenazin telah diterokai daripada sumber semula jadi dan boleh bertindak sebagai antibakteria, antikanser, antivirus, antitumor serta antiparasit. Setakat ini, kajian biosintesis fenazin yang telah dijalankan terhadap Pseudomonas dan Streptomyces telah mendedahkan gen yang bertanggungjawab dalam tapak jalan biosintesis fenazin, namun begitu, gen khusus yang terlibat dalam penghasilan terbitan fenazin yang kompleks masih dalam hipotesis. Dalam ulasan ini, kami membincangkan kepentingan fenazin serta pemahaman terkini tentang tapak jalan biosintesis fenazin yang berjaya diterokai di dalam Streptomyces kebangsaanensis.

Kata kunci: Antibiotik; biosintesis; fenazin; Streptomyces kebangsaanensis

\section{ABSTRACT}

Phenazine is a secondary metabolite that is naturally synthesized by Pseudomonas and Streptomyces. It is a heterocyclic compound that has nitrogen group at the core structure of the ring. The study of antibiotics has begun since 19th century and turned out to be a highly potential drug in a medical world. To date, more than 100 types of phenazines have been discovered from natural sources and acted as antibacterial, anticancer, antiviral, antitumor and antiparasites. To date, the study of phenazine biosynthesis was carried out on Pseudomonas and Streptomyces has showed the genes responsible in the pathway of phenazine biosynthesis but the specific genes involved in the production of complex phenazine derivatives are still hypothetical. In this review, we discuss the importance of phenazine as well as the latest understanding of phenazine biosynthesis pathways that have been successful discovered in Streptomyces kebangsaanensis.

Keywords: Antibiotics; biosynthesis; phenazine; Streptomyces kebangsaanensis

\section{PENGENALAN}

Fenazin terdiri daripada kumpulan heterosiklik yang mempunyai sebatian nitrogen pada teras cecincinnya (Rajah 1). Kepelbagaian kumpulan berfungsi yang hadir menentukan keunikan ciri kimia dan biologinya. Sehingga kini, lebih daripada 100 jenis fenazin dengan struktur terbitan yang berbeza telah dikenal pasti secara semula jadi dan lebih 7000 sebatian yang mempunyai teras fenazin telah berjaya disintesis didepositkan ke dalam laman sesawang NCBI (https://www.ncbi.nlm.nih.gov/ search/?term=phenazine; tarikh capaian: 01 Jun 2018). Fenazin yang dihasilkan secara semula jadi oleh bakteria mahupun disintesis secara kimia menjadi tarikan ramai penyelidik disebabkan potensinya dalam bidang perubatan dan bioteknologi (Pierson \& Pierson 2010).

Antara fenazin yang telah berjaya dikomersialkan dalam bidang perubatan adalah clofazimine (Lamprene, Novartis) yang mula dipreskripsi oleh para doktor pada tahun 1957 sebagai antileprosi dan sebagai antiinflamasi dalam mengawal reaksi seperti erythema nodosum leprosum (daripada label rasmi FDA) (Arbiser \& Moschella

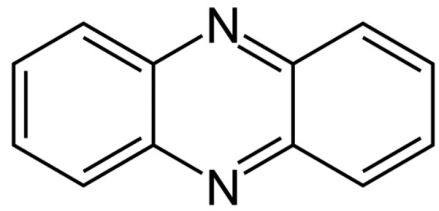

RAJAH 1. Fenazin merupakan kompaun heterosiklik dan mempunyai sebatian bernitrogen pada struktur teras cecincin.

Kepelbagaian terbitan struktur terbitan fenazin menghasilkan aktiviti biologi yang berbeza

Sumber: Laursen dan Nielsen 2004

1995). Sebatian ini, adalah analog kepada fenazin sintetik yang berasal daripada riminofenazin dan asalnya ditemui pada Lichens (Mavrodi et al. 2006; Reddy et al. 1999). Sis (fenazin-1-karboksamida) pula bertindak sebagai dadah sitotoksik yang kuat dan dikelaskan sebagai agen antikanser dalam merencat enzim topoisomerase I/II (Spicer et al. 2000).

Menariknya, berbanding terbitan fenazin yang disintesis secara kimia, hampir semua sebatian fenazin 
yang disintesis secara semula jadi mempunyai aktiviti yang berspektrum luas (Jadual 1) (Guttenberger et al. 2017; Laursen \& Nielsen 2004; Mavrodi et al. 2010). Fenazin turut berperanan penting sebagai agen biokawalan berdasarkan ciri-cirinya sebagai antibakteria dan antifungus (Laursen \& Nielsen 2004; Mavrodi et al. 2006). Kajian terdahulu membuktikan bahawa fenazin yang dihasilkan daripada kolonisasi Pseudomonas fluorescens 2-79 dan Pseudomonas aureofaciens 30-80 pada akar pokok gandum memberikan potensi aktiviti biologi yang sangat baik dalam merencat beberapa jangkitan fungus pada tumbuhan (Pierson et al. 1995). Sebagai contoh, fenazin-1-asid karboksilik (PCA) mampu memulihkan penyakit akar yang teruk pada gandum yang disebabkan oleh Gaeumannomyces framinis var. tritici (Thomashow \& Weller 1988; Thomashow et al. 1990).

Juga, fenazin-1-karboksamida (PCN) yang dihasilkan oleh Pseudomonas chloraphis PCL 1391 dapat merencat penyakit akar pada tomato yang disebabkan oleh jangkitan Fusarium oxysporum $f$. sp. Radicislycopersici; namun begitu fenazin-1-karboksilik asid (PCA) yang dihasilkan oleh P. fluorescens 2-79 dilaporkan tidak berjaya merencat penyakit ini (Weong et al. 1998). Fenazin-1- asid karboksilik yang juga dikenali sebagai Tubermycin B mampu menentang Mycobacterium tuberculosis dan turut merencat pertumbuhan Bacillus cereus dengan kepekatan minimum perencatan (MIC) serendah $0.5 \mu \mathrm{g} / \mathrm{mL}$ (Jayatilake et al. 1996). Strain Erwinia herbicola Eh1087 yang berjaya dipencilkan daripada pokok di sebuah kebun tanaman di Canterbury, New Zealand turut menghasilkan antibiotik fenazin D-alanylgriseoluteik (AGA) (Giddens et al. 2002) yang berpotensi mengawal serangan gejala terbakar atau dikenali sebagai fireblight symptom pada buah epal dan pir yang disebabkan fitopatogen Erwinia amylovora (Giddens et al. 2003; Kearns \& Hale 1996). Rajah 2 merupakan koleksi beberapa terbitan fenazin yang dihasilkan secara semula jadi.
Selain dibuktikan dapat merencat pelbagai mikroorganisma, fenazin juga memainkan peranan penting dalam fisiologi bakteria. Hernandez et al. (2004) mencadangkan fenazin menyumbang kepada pengambilan mineral besi di dalam bakteria dengan menurunkan ion $\mathrm{Fe}^{3+}$ kepada ion $\mathrm{Fe}^{2+}$ yang lebih larut seterusnya diperangkap oleh siderofor untuk proses mekanisme selanjutnya. Sesetengah fenazin juga memainkan peranan penting untuk pengeluarnya tersendiri. Contohnya, pyocyanin yang bertindak sebagai molekul isyarat kimia dalam $P$. aeruginosa secara langsung mengaktifkan faktor transkrip besi iaitu SoxR seterusnya mengawal pelbagai gen yang terlibat dalam pengangkut transmembran dan membawa kepada reaksi tekanan oksidatif (Dietrich et al. 2006).

Pyocyanin adalah metabolit fenazin pertama yang pernah dipencilkan seawal abad ke-19. Pyocyanin berasal daripada perkataan Yunani; 'pyo' yang bermaksud nanah dan 'cyanin' bermaksud biru daripada pemerhatian dan pencirian daripada Joseph Maturin Fordos yang mendapati luka bernanah pesakit berubah menjadi biru (Fordos 1860). Walau bagaimanapun, sehingga 1882 , barulah dikenal pasti bahawa pyocyanin dihasilkan oleh mikroorganisma (Gessard 1882). Bakteria yang sama pernah dikenal pasti oleh Schroeter satu dekad lebih awal tanpa merujuk kepada kajian Fordos yang dikenali sebagai Bacterium aeruginosum (Schroeter 1872) dan seterusnya dikenali sebagai Pseudomonas aeruginosa sehingga kini. Pada tahun 1889 , pyocyanin ini mampu untuk membunuh pelbagai jenis bakteria dan seterusnya digunakan untuk merawat penyakit meningitis, influenza dan diphtheria sebelum beberapa dekad sebelum masuk abad ke-20 (Schoental 1941). Walau bagaimanapun, hampir 100 tahun kemudian, barulah struktur kimia pyocyanin diterbitkan (Ledderhose 1888).

Pada pertengahan abad ke-20, fenazin dikenal pasti turut dihasilkan oleh pelbagai mikroorganisma lain seperti

JADUAL 1. Beberapa fenazin terbaru yang dipencilkan daripada spesies semula jadi (kecuali Clofazimine secara sintetik) yang menunjukkan struktur dan aktiviti yang memberangsangkan. Struktur A-I adalah struktur kimia baru yang masih belum dinamakan

\begin{tabular}{|c|c|c|c|}
\hline Struktur & Kesan biologi & spesies & Rujukan \\
\hline phenazoline A, B, C & $\begin{array}{c}\text { Antikanser pada sel selanjar P388, GLC dan } \\
\text { H460. Juga bertindak sebagai antibakteria }\end{array}$ & Streptomyces sp. & Ding et al. (2011) \\
\hline pontemazine $\mathrm{A}, \mathrm{B}$ & $\begin{array}{l}\text { Pelindung sel neuron daripada kerosakan yang } \\
\text { dirangsang oleh glutamate. } \\
\text { Antikanser pada sel leukemia murin P388 }\end{array}$ & Bacillus sp. & Cha et al. (2015) \\
\hline $\begin{array}{l}\text { 5-methy phenazine } \\
\text { 1-carboxylic acid }\end{array}$ & Antikanser pada sel peparu A549 & P.putida & Kennedy et al. (2015) \\
\hline $\begin{array}{l}\text { Lavanducyanin } \\
\text { Struktur A } \\
\text { Struktur B }\end{array}$ & $\begin{array}{c}\text { Antikanser pada sel payudara MDA-MB-231. } \\
\text { Juga bertindak sebagai antibakteria dan } \\
\text { antioksida. }\end{array}$ & Streptomyces sp. & $\begin{array}{l}\text { Kondratyuk et al. } \\
\qquad(2015)\end{array}$ \\
\hline $\begin{array}{l}\text { Izuminoside A, B, C } \\
\text { Aotaphenazine }\end{array}$ & $\begin{array}{l}\text { Merencat sel kanser adenokarsinoma gastrik } \\
\text { pada manusia (AGS) }\end{array}$ & Streptomyces sp. & $\begin{array}{l}\text { Abdelfattah et al. } \\
\quad(2016,2011)\end{array}$ \\
\hline Struktur D, E, F, G, H, I & Antiviti antibakteria & Kitasatospora sp. & Wu et al. (2015) \\
\hline Clofazimine & $\begin{array}{c}\text { Antibakteria terhadap tuberculosis rintang } \\
\text { pelbagai dadah (MDR-TB) }\end{array}$ & Sintetik & Cholo et al. (2011) \\
\hline
\end{tabular}


<smiles>NC(=O)c1cccc2c1Nc1ccccc1[N-]2</smiles>

Chlororaphin

(P. cloraphis)<smiles>O=C(O)c1cccc2nc3ccccc3nc12</smiles>

fenazin-1-karboksilik asid (PCA)<smiles>Cc1cccc(O)c1C(=O)OC(C)c1cccc2nc3c(C(=O)O)cccc3nc12</smiles>

Saphenamycin

(S. canaries)<smiles>NC(=O)c1cccc2nc3ccccc3nc12</smiles>

Fenazin-1-karboksamida

(P. aeruginosa)<smiles>c1ccc2nc3ccccc3nc2c1</smiles>

Fenazin<smiles>CC1=C(O)CCC1O</smiles><smiles>COc1ccc(CO)c2nc3cccc(C(N)=O)c3nc12</smiles><smiles></smiles>

Sendomycin A (S. cinnamonensis)<smiles>Cn1c2cccc(=O)c-2nc2ccccc21</smiles>

Pyocyanin

(P. aeruginosa)<smiles>O=C(O)c1cccc2nc3c(C(=O)O)cccc3nc12</smiles>

Fenazin-1,6-dikarboksilik asid (PDC)

RAJAH 2. Koleksi beberapa terbitan fenazin yang dihasilkan secara semula jadi. PCA dan PDC (baris kedua) bertindak sebagai prekursor dalam biosintesis fenazin. Streptomyces menghasilkan sebatian yang lebih kompleks (baris ketiga). Saphenamycin adalah sebatian yang paling mimik dengan sebatian dari S. kebangsaanensis setakat ini

Sumber: Modifikasi daripada Laursen dan Nielsen (2004)

Methanosarcina maze (Archebacterium) (Abken et al. 1998), Pantoea agglomerans Eh1087 (Enterobacteriaceae) (Giddens et al. 2003), Burkholderia cepacia dan B. phenazinium (Proteobacteria) (Brisbane et al. 1987; Woeng et al. 1998) serta Pelagobacter variabilis dan Vibrio (Laursen \& Nielsen 2004; Turner \& Messenger 1986). Namun begitu, mikroorganisma ini tidak diketahui samada pengeluar fenazin secara eksklusif seperti Pseudomonas dan Streptomyces atau sebaliknya. Walau bagaimanapun, bukti terbaru mencadangkan gen yang bertanggungjawab dalam mengekodkan struktur teras fenazin berpindah antara pelbagai genus bakteria seperti Pseudomonas flourescens 2-79, Pseudomonas aeruginosa PAO1, Enterobacter agglomerans Eh1087, Strepromyces cinnamonensis DSM1042 dan Streptomyces antibioticus Tu2706 melalui pemindahan gen secara mendatar (Mavrodi et al. 2010; Pierson \& Pierson 2010).

Sementara strain Pseudomonas menghasilkan terbitan fenazin dengan struktur relatif yang biasa, Streptomyces pula dikaitkan dengan struktur fenazin yang lebih kompleks yang biasanya mempunyai lebih daripada satu gantian kumpulan berfungsi seperti amida, aldehida ester dan tioester (Guttenberger et al. 2017). Ini termasuk lomofungin daripada Streptomyces lomondensis (Johnson \& Dietz 1969) dan endofenazin daripada Streptomyces anulatus (Gebhardt et al. 2002; 
Krastel et al. 2002). Pseudomonas spp. pula menghasilkan sebatian fenazin yang lebih ringkas seperti Pseudomonas fluorescens yang menghasilkan PCA (Thomashow et al. 1990) dan Pseudomonas aeruginosa yang menghasilkan 2-hikroksilfenazin (Smirnov \& Kiprianova 1990), dengan masing-masing mempunyai tambahan kumpulan berfungsi karboksil dan hidroksil.

Bukti yang terkumpul daripada pelbagai penyelidikan mencadangkan terbitan fenazin mempunyai aktiviti yang luas dengan potensi biologi yang tinggi (Wang et al. 2011). Kekompleksan tinggi kumpulan berganti pada tulang belakang fenazin biasanya dikaitkan dengan aktiviti biologi yang lebih besar dan tinggi. Oleh itu, berbanding dengan Pseudomonas, spesies Streptomyces dianggap sebagai sumber semula jadi yang menjanjikan produk fenazin yang lebih berpotensi daripada segi aktiviti biologi. Atas alasan ini, banyak usaha dilakukan dalam mengenal pasti laluan biosintesis fenazin dan pasangan gen yang terlibat.

\section{MEKANISME TINDAK BALAS FENAZIN}

Fenazin biasanya bertindak melalui beberapa mekanisme termasuklah perlekatan pada DNA, tindak balas pada topoisomerase, melalui antipengoksidaan ataupun melalui pertukaran pada cas-cas molekul tertentu.

Fenazin yang mempunyai struktur aromatik seperti planar mempunyai struktur teras yang hampir sama seperti phenoxazines (actinomisin), daunomisin, kromomisin dan ethidium bromide yang sebelum ini memang dikenal pasti dengan mekanismenya ke atas perlekatan pada DNA (Laursen \& Nielsen 2004). Persamaan daripada struktur ini mencadangkan bahawa fenazin turut berkongsi mekanisme yang sama. Beberapa terbitan fenazin seperti iodinin, myxin dan pyocyanin menunjukkan berlaku perencatan pada templat DNA yang mengawal sintesis RNA, dengan perencatan berlaku sama ada melalui penyekatan pada templat DNA, perlekatan pada RNA polimerase ataupun perlekatan pada ribonucleoside-5'-triphosphate (Hollstein \& Van Gemert 1971). Myxin yang menunjukkan kesan yang paling signifikan telah digunakan sebagai rawatan antikanser dalam bidang veterinar yang dikenali sebagai cuprimyxin (Turner \& Messenger 1986). Mekanisme yang sama turut diperhatikan di dalam lomofungin yang merencat DNA dengan menghalang faktor transkrip untuk memulakan proses pemanjangan.

Topoisomerase I dan II pula adalah enzim yang bertanggungjawab untuk perubahan topologi DNA semasa pembahagian sel seperti penguraian, pengumpalan mahupun percantuman. Walau bagaimanapun, sel yang pesat membahagi seperti sel kanser mempunyai kepekatan topoisomerase yang sangat tinggi, justeru, perencatan pada enzim ini menjanjikan potensi yang tinggi sebagai sasaran dalam rawatan antikanser. Sis(fenazin-1-karboksamida) adalah antara fenazin sintetik yang bertindak melalui mekanisme perencatan pada topoisomerase I/II yang mempunyai beberapa reseptor yang boleh bertindak pada selang masa berbeza semasa kitaran pembahagian sel (Stewart et al. 2001).
Penghasilan molekul radikal adalah mekanisme terbanyak yang berlaku oleh fenazin. Walaupun sebahagian kesan biologi terbitan fenazin dikaitkan dengan tindakannya yang mampu menguraikan DNA, tetapi kebanyakannya bertindak melalui aktiviti penurunan redoks (Laursen \& Nielsen 2004). Dalam sel yang normal, radikal bebas dihasilkan secara semula jadi oleh mitokondria dan merupakan sebahagian daripada proses metabolik enzim untuk penghasilan tenaga. Bahkan, radikal bebas juga digunakan oleh badan sebagai salah satu respons imun sistem dalam melawan kehadiran patogen serta penguraian toksin dalam badan. Walau bagaimanapun, penghasilan radikal bebas yang berlebihan meningkatkan mutasi selular yang seterusnya membawa kepada kematian sel (Delaney et al. 2001; Hassan \& Fridovich 1980).

Sebagai contoh, fenazin mampu menurunkan molekul oksigen kepada spesies oksigen reaktif (ROS) seperti superoksida $\left(\mathrm{O}_{2}^{-}\right)$, hikroksil $\left(\mathrm{OH}^{-}\right)$dan hidrogen peroksida $\left(\mathrm{H}_{2} \mathrm{O}_{2}\right)$ yang bertindak sebagai radikal bebas yang aktif (Kerr 2000). Radikal bebas ini boleh menyebabkan kerosakan secara signifikan pada struktur sel sama ada dengan cara merosakkan rantaian DNA, pengoksidaan pada lipid, asid amino ataupun dengan menyahaktifkan fungsi enzim. Tindakan ini secara langsung menerangkan bagaimana aktiviti antibiotik ini bertindak dan juga menjawab persoalan bagaimana fenazin boleh turut bertindak sebagai faktor virulen yang memburukkan keadaan penyakit berjangkit (Lau et al. 2004a). Keadaan ini dapat dilihat pada pesakit yang mendapat jangkitan paruparu oleh $P$. aeruginosa, menunjukkan metabolit fenazin bertoksik dikenali sebagai pyocyanin yang dirembeskan oleh mikroorganisma ini menyebabkan inflamasi yang berterusan pada pesakit (Lau et al. 2004b). P. aeruginosa yang merupakan patogen oportunistik manusia sangat penting dalam menyebabkan jangkitan nosokomial di hospital mampu memendekkan jangka hayat pesakit dengan penyakit kronik cystic fibrosis yang berpanjangan dan akhirnya membawa kepada kematian (Emerson et al. 2002). Sehingga kini, pyocyanin yang dicirikan dengan pigmen biru masih menjadi kayu ukur kepada pengenalpastian $P$. aeruginosa di hospital mahupun dalam bidang penyelidikan.

Tubermycin B (atau dikenali sebagai fenazin-1asid karboksilik (PCA) (Rajah 2) dan 6-((2-hidroksil-4metoksilfenoksil)karbonil) fenazin-1-karboksilik asid (HCPCA) (Rajah 3(a)) adalah dua metabolit fenazin yang berjaya dipencilkan daripada S. kebangsaanensis (Remali et al. 2017; Sarmin et al. 2013). Walau bagaimanapun, HCPCA mempunyai persamaan struktur yang paling hampir dengan saphenamycin; metabolit fenazin yang berasal daripada asid safenik. Saphenamycin sebelum ini ditunjukkan mempunyai aktiviti biologi yang berspektrum luas termasuk antibakteria, antitumor dan juga antilarvasidal pada nyamuk (Geiger et al. 1988; Kitahara 1982; Laursen \& Nielsen 2004). Selain itu, metabolit yang berasal daripada asid safenik mempunyai aktiviti biologi termasuklah sebagai antibiotik dan sebagai pemerangkap radikal bebas (Laursen \& Nielsen 2004). Ini mencadangkan 
terbitan fenazin yang dihasilkan oleh $S$. kebangsaanensis ini mungkin turut berkongsi tapak mekanisme dan aktiviti biologi yang sama. Saphenamycin yang berjaya dipencilkan daripada $S$. canaries menunjukkan aktiviti antibiotik yang sangat tinggi, terutamanya terhadap bakteria Gram positif dengan MIC $<0.001-0.35 \mu \mathrm{g} / \mathrm{mL}$. Saphenamycin juga mampu membunuh $50 \%$ populasi sel selanjar kanser dengan kepekatan $0.6 \mu \mathrm{g} / \mathrm{mL}$ dan kompaun ini mampu untuk meningkatkan jangka hayat mencit yang diimplantasi dengan sel leukemia (Geiger et al. 1988; Kitahara 1982). Terbitan asid safenik, iaitu 3-hidroksi-2-metoksipropionik yang dipencilkan daripada Streptomyces luteogriseus menunjukkan aktiviti yang aktif menentang bakteria Gram positif ( $\mathrm{MIC}<0.1-0.3 \mu \mathrm{g} / \mathrm{mL}$ ) dan juga mampu membunuh tumor murin $\left(\mathrm{LD}_{50}:<25 \mathrm{mg}\right.$ / kg) (Asano et al. 1986; Takahashi et al. 1988). Selain itu, terbitan phenazostatin A, B dan C daripada asid safenik yang dipencilkan daripada Streptomyces sp. 833 dibuktikan mempunyai mekanisme pendakap radikal bebas dengan melindungi sel neuron daripada toksisiti glutamat yang boleh menyebabkan demensia (kegilaan) (Kim et al. 1997; Yun et al. 1996).

Oleh itu, terbitan fenazin yang hampir sama dengan saphenamycin (Rajah 3) seperti phenazostatin mencadangkan fenazin yang dipencilkan daripada $S$. kebangsaanensis mungkin mempunyai mekanisme yang sama untuk bertindak sebagai pendakap radikal bebas serta mempunyai aktiviti antibiotik dan juga antikanser. Walau bagaimanapun, kajian lanjutan mengenai fenazin daripada S. kebangsaanensis perlu dilakukan untuk mengenal pasti mekanisme tindakan dan biosintesisnya.

\section{BIOSINTESIS FENAZIN}

Fenazin semula jadi dipercayai adalah metabolit sekunder yang terhasil daripada metabolit primer. Fenazin yang dihasilkan oleh sel yang telah berhenti membahagi dan dimetabolisme secara perlahan-lahan menunjukkan tiada fungsi yang jelas dalam pertumbuhan sel mahupun sebagai

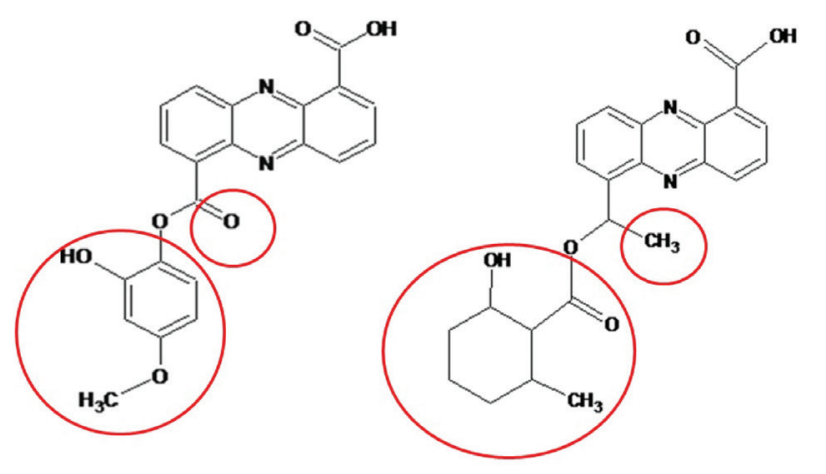

(a)

(b)

RAJAH 3. Terbitan fenazin yang hampir sama dengan saphenamycin seperti phenazostatin mencadangkan fenazin yang dipencilkan daripada $S$. kebangsaanensis mungkin mempunyai mekanisme tindakan dan biosintesis yang sama sumber tenaga (Laursen \& Nielsen 2004). Kebanyakan kajian laluan biosintesis fenazin yang dijalankan ke atas strain Pseudomonas, walau bagaimanapun, hasil kajian daripada Streptomyces menyokong fenazin yang dihasilkan mempunyai laluan biosintesis yang sama. Telah dibuktikan bahawa struktur fenazin teras mempunyai tiga cecincin heterosiklik terdiri daripada fenazin-1-karboksilik asid (PCA) ataupun fenazin-1,6-dikarboksilik asid (PDC) yang akan menjadi prekursor untuk membentuk struktur fenazin yang lebih kompleks bergantung kepada spesies bakteria (Laursen \& Nielsen 2004). Terbukti proses biosintesis struktur fenazin teras bagi kompaun fenazin pencilan Streptomyces dan Pseudomonas bermula dengan asid sikimik (Laursen \& Nielson 2004; Van't Land et al. 1993). Seterusnya, asid korismik disintesis melalui laluan sikimat dan mekanisme pemangkin penukaran asid sikimik kepada asid korismik berlaku seperti yang ditunjukkan dalam Rajah 4 (Mavrodi et al. 2006).

Penyelidikan tentang laluan biosintesis fenazin telah dikaji secara mendalam dengan Pierson et al. (1995) mengenal pasti gen-gen yang bertanggungjawab untuk penghasilan fenazin dalam $P$. aureofaciens. Tidak lama kemudian, lokus biosintesis fenazin turut dikenal pasti, diklon dan dijujuk dalam $P$. fluorescens (Mavrodi et al. 1998) dan P. aeruginosa (Mavrodi et al. 2001). Lokus ini terdiri daripada tujuh-gen yang terpelihara dalam operon phzABCDEFG dengan kehadiran ketujuh-tujuh gen ini memadai untuk penghasilan PCA daripada asid korismik. Menariknya, $P$. aeruginosa mempunyai dua salinan operon dalam biosintesis fenazin (Mavrodi et al. 2001) dan ia terbukti memainkan peranan yang berbeza dalam patogenesis yang disebabkan oleh bakteria ini (Recinos et al. 2012). Walau bagaimanapun, diketahui bahawa PCA merupakan prekursor dalam penghasilan fenazin di dalam Pseudomonas manakala PDC biasa diubah suai untuk menghasilkan struktur fenazin yang lebih kompleks di dalam Streptomyces (McDonald et al. 2001; Turner \& Messenger 1986; Van’t Land et al. 1993). Sehingga kini, pelbagai variasi operon fenazin telah ditemui oleh pengeluar fenazin daripada bakteria Gram positif dan Gram negatif. Dilaporkan juga bahawa kelompok gen ini berpindah antara genus bakteria melalui transmisi secara mendatar (Fitzpatrick 2009; Mavrodi et al. 2010). Perbandingan operon fenazin daripada spesies berbeza mendapati lima enzim, $p h z B, p h z D, p h z E, p h z F$ dan $p h z G$ berada dalam kesemua bakteria. Enzim ini menukarkan korismat kepada fenazin-1-karboksilik (PCA) asid ataupun fenazin-1,6-dikarboksilik asid (PDC) yang bertindak sebagai struktur fenazin teras manakala enzim-enzim lain yang mengekodkan di luar atau di dalam operon bertindak untuk membentuk terbitan fenazin yang spesifik terhadap strain masing-masing (Blankenfeldt 2013).

Dalam S. kebangsaanensis, kami mencadangkan bahawa pembentukan sebatian HCPCA adalah berasal daripada gabungan metabolit PDC dan 4-methoxybenzene1,2-diol dan bermula daripada laluan asid sikimik (Remali et al. 2017). Seterusnya, penghasilan prekursor fenazin1-karboksilik asid (PCA) dan fenazin-1,6-dikarboksilik 


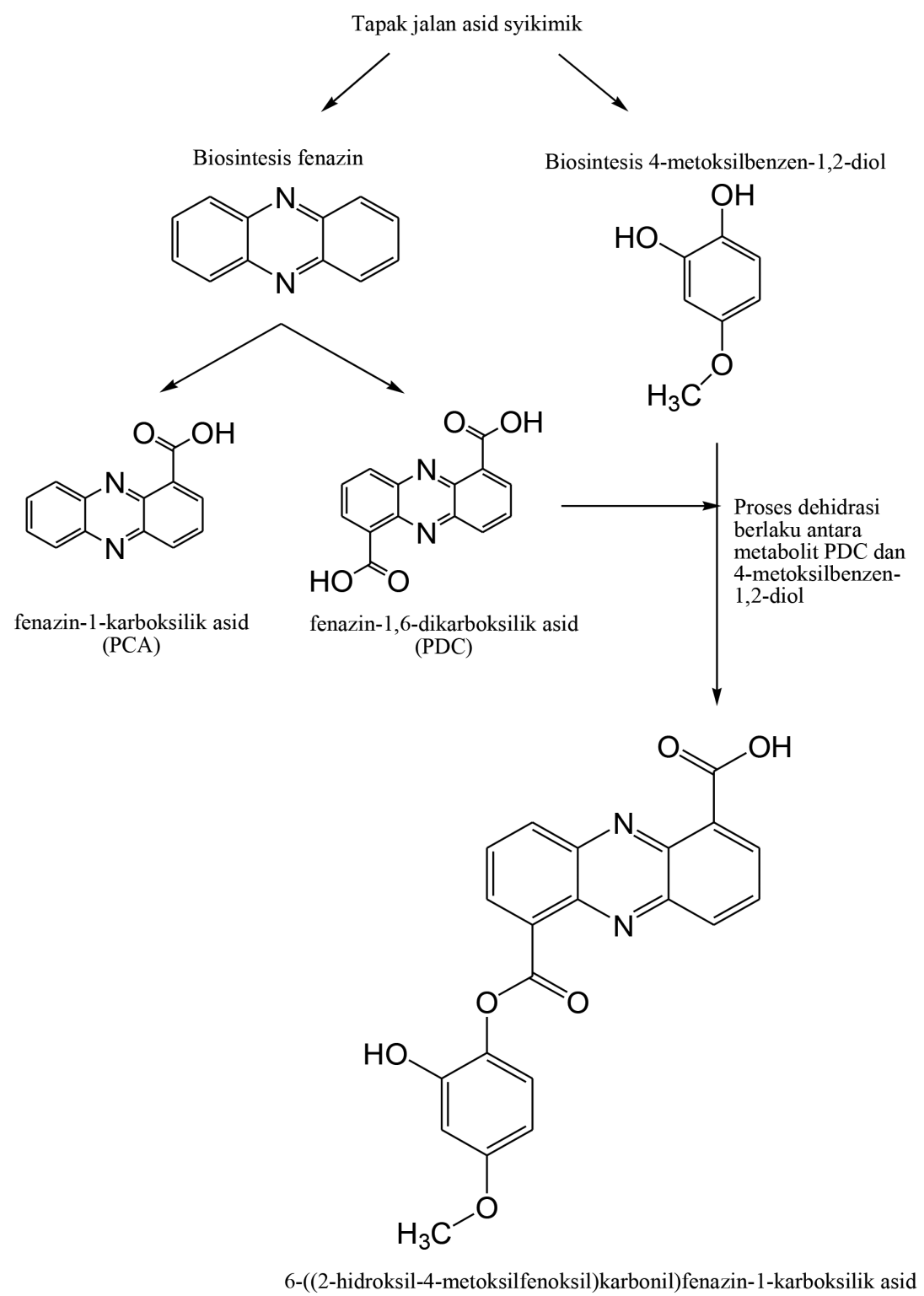

RAJAH 4. Ringkasan keseluruhan cadangan tapak jalan biosintesis fenazin dalam S. kebangsaanensis

asid (PDC) terbentuk melalui mekanisme yang pernah dicadangkan oleh beberapa penyelidik terdahulu seperti Blankenfeldt (2013) dan Mavrodi et al. (2013). Sebagai mana telah dibincangkan sebelum ini, metabolit PDC yang terbentuk biasanya diubah suai untuk menghasilkan struktur fenazin yang lebih kompleks dalam Streptomyces (McDonald et al. 2001; Turner \& Messenger 1986; Van't Land et al. 1993). Dicadangkan PDC yang dihasilkan oleh $S$. kebangsaanensis bergabung dengan metabolit 4-metoksilbenzene-1,2-diol melalui proses dehidrasi pada salah satu kumpulan berfungsi hidroksil $(\mathrm{OH})$ yang terdapat pada PDC dan metabolit 4-metoksilbenzene-1,2diol untuk pembentukan akhir sebatian 6-((2-hidroksil4-metoksilfenoksilkarbonil)fenazin-1-karboksilik asid (HCPCA). Gambaran keseluruhan tapak jalan yang berlaku dalam S. kebangsaanensis diringkaskan dalam Rajah 4. Kami turut menemui beberapa gen yang unik yang dicadangkan terlibat dalam penghasilan metabolit HCPCA.
Walau bagaimanapun, kajian lanjutan seperti mutagenesis perlu dilakukan untuk mengesahkan keputusan ini (Remali et al. 2017).

Dalam biosintesis fenazin daripada S. kebangsaanensis, pembentukan metabolit fenazin bermula samada daripada fenazin-1-karboksilik asid (PCA) ataupun fenazin-1,6dikarboksilik asid (PDC). Menariknya, S. kebangsaanensis yang menghasilkan dua fenazin ditunjukkan untuk menggunakan PCA dan PDC sebagai prekursor dalam penghasilan antibiotik fenazin. Tubermycin B yang dipencilkan ditunjukkan secara langsung membentuk PCA manakala sebatian terbitan novel daripada $S$. kebangsaanensis ditunjukkan menggunakan precursor PDC untuk membentuk kompleks antibiotik fenazin memandangkan PDC mempunyai posisi kumpulan berganti pada lokasi 1,6. Keadaan ini mencadangkan bahawa tapak jalan biosintesis fenazin adalah sama seperti yang dicadangkan oleh Mavrodi et al. (2013) sebelum ini dalam 


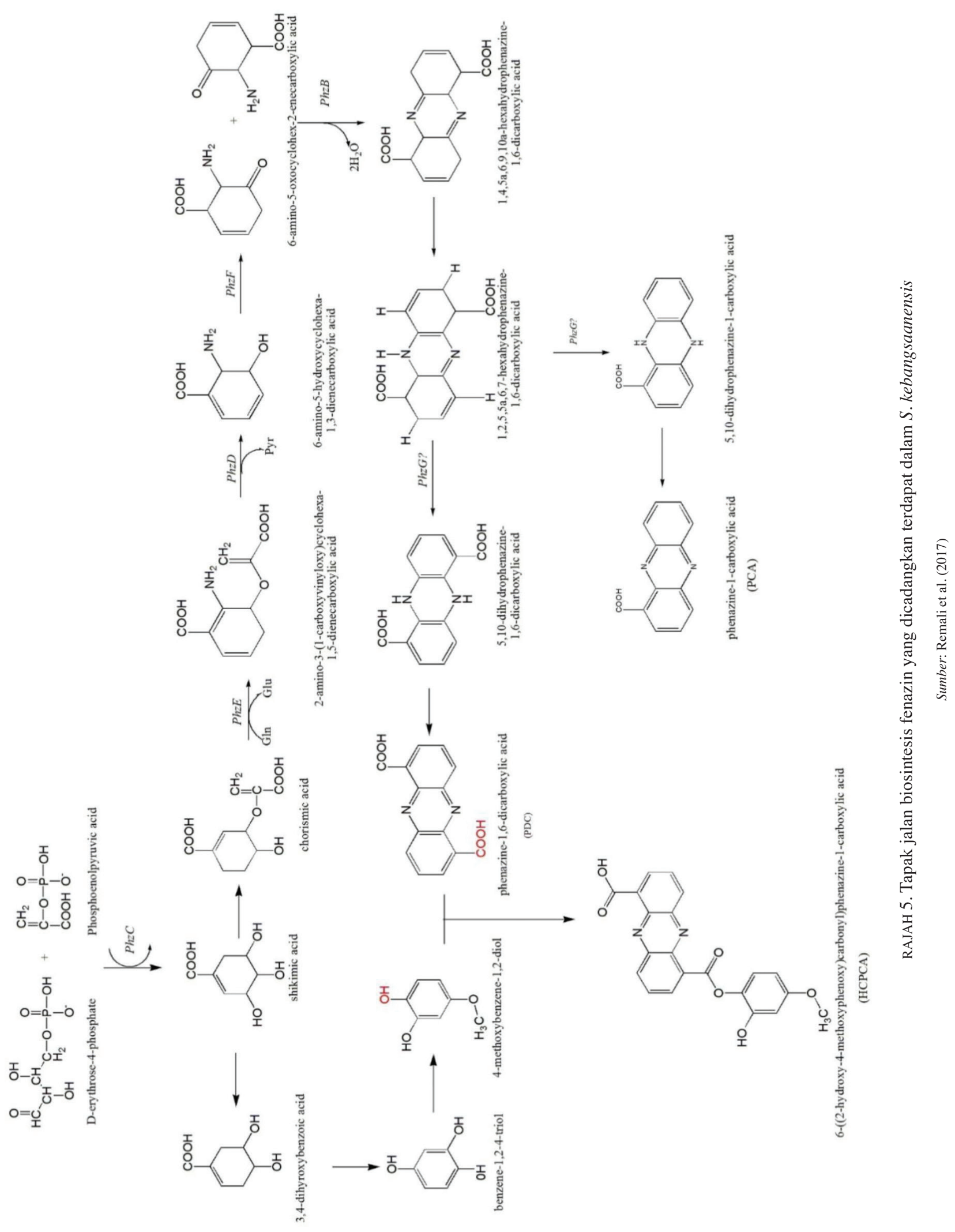


membentuk prekursor PCA dan PDC. S. kebangsaanensis tidak mempunyai phzG dalam laluan biosintesis yang dicadangkan oleh Mavrodi et al. (2013). Dicadangkan bahawa terdapat jujukan gen lain yang menggantikan fungsi gen phzG yang bertindak dalam tapak jalan biosintesis fenazin (Remali et al. 2017). Didapati gen 3288 daripada kajian kami berkongsi persamaan jujukan sebanyak $85 \%$ dengan kelas LLM oksidoreduktase bergantung-F420 yang terdapat dalam Streptomyces sp. FxanaA7, sejenis enzim seperti flavonoid bergantung enzim pyridoxine-50-fosfat oksidase (Selengut \& Haft 2010). Oleh itu, kami menbuat hipotesis bahawa gen 3288 mungkin berfungsi sebagai phzG untuk mengoksidasi HHPDC dalam laluan biosintesis fenazin dalam S. kebangsaanensis (Remali et al. 2017).

Laluan biosintesis fenazin teras terdiri daripada satu laluan asid syikimik yang bercabang sebelum syikimat ditukarkan kepada anthranilate (hasil daripada tindak balas phzE). Walau bagaimanapun, terdapat langkah kimia hiliran yang diperlukan untuk menukarkan metabolit kepada antranilate, oleh itu, terdapat lima metabolit perantara yang diperlukan sebelum biosintesis fenazin membentuk cabang biosintesis yang tersendiri. Ia adalah asid syikimik, syikimik-5-fosfat, 3-enolpyruvly-shikimate5-phosphate, asid korismik dan asid 2-amino-2-desoxyisochorismik, dengan gen yang terlibat dalam penghasilan metabolit perantara ini telah ditemui dalam genom $S$. kebangsaanensis mencadangkan kompaun ini berkongsi laluan biosintesis yang sama dalam menghasilkan fenazin. Hal ini turut disahkan dalam kajian beberapa produk fenazin semula jadi yang lain (Levitch \& Rietz 1966; Levitch \& Stadtman 1964; Podojil \& Gerber 1967).

Dalam penghasilan fenazin teras, dicadangkan $p h z C$, mengekodkan 3-deoxy-D-arabinoheptulosonate7-phosphate (DAHP) sintase, enzim yang memangkinkan langkah pertama laluan sikimat dalam biosintesis korismat (Rajah 5). Seterusnya, laluan biosintesis fenazin bermula dengan penukaran asid korismik kepada 2-amino-3-(1carboksiviniloksi)sikloheksa-1,5-dienecarboxylic acid (ADIC) (Rajah 5), yang sebelum ini pernah diutarakan sebagai perkursor fenazin oleh Römer dan Herbert (1982). Langkah seterusnya dalam biosintesis fenazin dimangkinkan oleh $p h z D$, yang menghidrolisiskan ADIC kepada piruvat dan 6-amino-5-hydroxycyclohexa-1,3dienecarboxylic asid (AHDA) (McDonald et al. 2001). Seterusnya, penglibatan $p h z F, B / A$ dan $G$ diperlukan dalam tapak jalan biosintesis fenazin (Rajah 5).

AHDA seterusnya mengalami pengoksidaan oleh FMN-dependent enzyme $p h z G$ (McDonald et al. 2001) dan ditunjukkan bahawa DHHA adalah substrat kepada $p h z F$ dan ia bertindak dengan isomerilisasi kepada asid 6-amino-5-oxo-cyclohex-2-enecarboxylik (AOCHC) seperti yang ditunjukkan dalam Rajah 5 (Blankenfeldt et al. 2004; Parson et al. 2004a). AOCHC adalah sangat reaktif dan tidak boleh dipencilkan terus bertindak dengan molekul kedua AOCHC, menghasilkan satu isomer imine berganda iaitu asid hexahydrophenazine-1,6-dicarboxylik (HHPDC) (Blankenfeldt et al. 2004). Ia menunjukkan bahawa $p h z B$ memangkinkan proses kondensasi seterusnya (Hollstein et al. 1978). Oksidasi dua elektron kedua dilakukan oleh phzG (Blankenfeldt 2013), enzim bersandar-FMN dan strukturnya hampir sama dengan pyridoxine-5'-phosphate oksidase PdxH (Parson et al. 2004b) untuk membentuk PCA atau PDC (Parson et al. 2004b). Ini memberi petunjuk bahawa biosintesis fenazin mengikut prinsip yang sama dalam kesemua pengeluar bakteria fenazin, dan kepelbagaian terbitan fenazin yang ditemui dalam alam semula jadi adalah akibat daripada modifikasi yang diaplikasikan pada perkursor molekul (Mentel et al. 2009).

\section{TAMBAH KESIMPULAN}

Terbitan fenazin novel yang diperoleh daripada pemisahan sebatian tulen meningkatkan keyakinan bahawa spesies novel mempunyai gen novel yang bertindak dalam menghasilkan terbitan baru. Walaupun kajian biosintesis fenazin telah dilakukan terhadap Pseudomonas dan Streptomyces setakat ini telah mendedahkan gen-gen yang bertanggungjawab dalam tapak jalan biosintesis fenazin, namun begitu gen-gen spesifik yang terlibat dalam penghasilan terbitan fenazin yang kompleks daripada spesies pengeluar dalam biosintesis fenazin masih hipotetikal. Hal ini membawa kepada motivasi dalam literatur ini dalam meneroka gen-gen yang bertanggungjawab dalam biosintesis fenazin yang terdapat dalam S. kebangsaanensis melalui pendekatan genomik.

\section{RUJUKAN}

Abdelfattah, M.S., Ishikawa, N., Karmakar, U.K., Yamaku, K. \& Ishibashi, M. 2016. New phenazine analogues from Streptomyces sp. IFM 11694 with TRAIL resistanceovercoming activities. Journal of Antibiotics 69(6): 446-450.

Abdelfattah, M.S., Toume, K. \& Ishibashi, M. 2011. Isolation and structure elucidation of izuminosides A-C: A rare phenazine glycosides from Streptomyces sp. IFM 11260. Journal of Antibiotics 64(3): 271-275.

Abken, H.J., Tietze, M., Brodersen, J., Bäumer, S., Beifuss, U. \& Deppenmeier, U. 1998. Isolation and characterization of methanophenazine and function of phenazines in membranebound electron transport of Methanosarcina mazei Gö1. Journal of Bacteriology 180(8): 2027-2032.

Arbiser, J.L. \& Moschella, S.L. 1995. Clofazimine: A review of its medical uses and mechanisms of action. Journal of the American Academy of Dermatology 32(2): 241-247.

Asano, K., Takahashi, K., Tomita, F. \& Kawamoto, I. 1986. DC86-M, a novel antitumor antibiotic. I. Taxonomy of producing organism and fermentation. The Journal of Antibiotics 39(5): 619-623.

Blankenfeldt W. 2013. The biosynthesis of phenazines. Dlm. Microbial Phenazines, disunting oleh Chincholkar, S. \& Thomashow, L. Springer, Berlin, Heidelberg. hlm. 1-17.

Blankenfeldt, W., Kuzin, A.P., Skarina, T., Korniyenko, Y., Tong, L., Bayer, P., Janning, P., Thomashow, L.S. \& Mavrodi, D.V. 2004. Structure and function of the phenazine biosynthetic protein PhzF from Pseudomonas fluorescens. Proceedings of the National Academy of Sciences of the United States of America 101(47): 16431-16436.

Brisbane, P.G., Janik, L.J., Tate, M. \& Warren, R. 1987. Revised structure for the phenazine antibiotic from Pseudomonas 
fluorescens 2-79 (NRRL B-15132). Antimicrobial Agents and Chemotherapy 31(12): 1967-1971.

Cha, J.W., Lee, S.Il, Kim, M.C., Thida, M., Lee, J.W., Park, J.S. \& Kwon, H.C. 2015. Pontemazines A and B, phenazine derivatives containing a methylamine linkage from Streptomyces sp. UT1123 and their protective effect to HT-22 neuronal cells. Bioorganic and Medicinal Chemistry Letters 25(22): 5083-5086.

Delaney, S.M., Mavrodi, D.V., Bonsall, R.F. \& Thomashow, L.S. 2001. phzO, a gen for biosynthesis of 2-hydroxylated phenazine compounds in Pseudomonas aureofaciens 30-84. Journal of Bacteriology 183(1): 318-327.

Dietrich, L.E., Price-Whelan, A., Petersen, A., Whiteley, M. \& Newman, D.K. 2006. The phenazine pyocyanin is a terminal signalling factor in the quorum sensing network of Pseudomonas aeruginosa. Molecular Microbiology 61(5): 1308-1321.

Ding, Z.G., Li, M.G., Ren, J., Zhao, J.Y., Huang, R., Wang, Q.Z., Cui, X.L.,Zhu, H.J.\& Wen, M.L. 2011. Phenazinolins A-E: Novel diphenazines from a tin mine tailings-derived Streptomyces species. Organic \& Biomolecular Chemistry 9(8): 2771-2776.

Emerson, J., Rosenfeld, M., McNamara, S., Ramsey, B. \& Gibson, R.L. 2002. Pseudomonas aeruginosa and other predictors of mortality and morbidity in young children with cystic fibrosis. Pediatric Pulmonology 34(2): 91-100.

Fitzpatrick, D.A. 2009. Lines of evidence for horizontal gene transfer of a phenazine producing operon into multiple bacterial species. Journal of Molecular Evolution 68(2): 171-185.

Fordos, M. 1860. Recherches sur la matière colorante des suppurations bleues: Pyocyanine. CR Acad.Sci. 51: 215-217.

Gebhardt, K., Schimana, J., Krastel, P., Dettner, K., Rheinheimer, J., Zeeck, A. \& Fiedler, H.P. 2002. Endophenazines AD, new phenazine antibiotics from the arthropod associated endosymbiont Streptomyces anulatus. I. Taxonomy, fermentation, isolation and biological activities. The Journal of Antibiotics 55(9): 794-800.

Geiger, A., Keller-Schierlein, W., Brandl, M. \& Zähner, H. 1988. Metabolites of microorganisms. 247. Phenazines from Streptomyces antibioticus, strain Tu 2706. The Journal of Antibiotics 41(11): 1542-1551.

Gessard, C. 1882. Sur les colorations bleue et verte des linges a pansements. Compt. Rend. Acad. Sci. 94: 536-568.

Giddens, S.R., Houliston, G.J. \& Mahanty, H.K. 2003. The influence of antibiotic production and pre-emptive colonization on the population dynamics of Pantoea agglomerans (Erwinia herbicola) Eh1087 and Erwinia amylovora in planta. Environmental Microbiology 5(10): 1016-1021.

Giddens, S.R., Feng, Y. \& Mahanty, H.K. 2002. Characterization of a novel phenazine antibiotic gen cluster in Erwinia herbicola Eh1087. Molecular Microbiology 45(3): 769-783.

Guttenberger, N., Blankenfeldt, W. \& Breinbauer, R. 2017. Recent developments in the isolation, biological function, biosynthesis, and synthesis of phenazine natural products. Bioorganic and Medicinal Chemistry 25(22): 6149-6166.

Hassan, H.M. \& Fridovich, I. 1980. Mechanism of the antibiotic action pyocyanine. Journal of Bacteriology 141(1): 156-163.

Hernandez, M.E., Kappler,A.\& Newman, D.K. 2004. Phenazines and other redox-active antibiotics promote microbial mineral reduction. Applied and Environmental Microbiology 70(2): 921-928.
Hollstein, U. \& Van Gemert Jr., R.J. 1971. Interaction of phenazines with polydeoxyribonucleotides. Biochemistry 10(3): 497-504.

Hollstein, U., Mock, D.L., Sibbitt, R.R., Roisch, U.\& Lingens, F. 1978. Incorporation of shikimic acid into iodinin. Tetrahedron Letters 19(33): 2987-2990.

Jayatilake, G.S., Thornton, M.P., Leonard, A.C., Grimwade, J.E. \& Baker, B.J. 1996. Metabolites from an Antarctic spongeassociated bacterium, Pseudomonas aeruginosa. Journal of Natural Products 59(3): 293-296.

Johnson, L.E. \& Dietz, A. 1969. Lomofungin, a new antibiotic produced by Streptomyces lomondensis sp. n. Applied Microbiology 17(5): 755-759.

Kearns, L. \& Hale, C. 1996. Partial characterization of an inhibitory strain of Erwinia herbicola with potential as a biocontrol agent for Erwinia amylovora, the fire blight pathogen. Journal of Applied Bacteriology 81(4): 369-374.

Kennedy, R.K., Naik, P.R., Veena, V., Lakshmi, B.S., Lakshmi, P., Krishna, R. \& Sakthivel, N. 2015. 5-Methyl phenazine1-carboxylic acid: A novel bioactive metabolite by a rhizosphere soil bacterium that exhibits potent antimicrobial and anticancer activities. Chemico-Biological Interactions 231: 71-82.

Kerr, J. 2000. Phenazine pigments; Antibiotics and virulence factors. Infectious Disease Review 2(4): 184-194.

Kim, W.G., Ryoo, I.J., Yun, B.S., Shin-Ya, K., Seto, H. \& Yoo, I.D. 1997. New diphenazines with neuronal cell protecting activity, phenazostatins A and B, produced by Streptomyces sp. The Journal of Antibiotics 50(9): 715-721.

Kitahara, M. 1982. Saphenamycin, a novel antibiotic from a strain of Streptomyces. Journal of Antibiotics 35(10): 1412-1414.

Krastel,P.,Zeeck,A., Gebhardt, K., Fiedler, H.P. \& Rheinheimer, J. 2002. Endophenazines AD, new phenazine antibiotics from the athropod associated endosymbiont Streptomyces anulatus II. Structure elucidation. The Journal of Antibiotics 55(9): 801-806.

Kondratyuk, T.P., Park, E.J., Yu, R., van Breemen, R.B., Asolkar, R.N., Murphy, B.T., Fenical, W.\& Pezzuto, J.M. 2012. Novel marine phenazines as potential cancer chemopreventive and anti-inflammatory agents. Marine Drugs 10(12): 451-464.

Lau, G.W., Hassett, D.J., Ran, H. \& Kong, F. 2004a. The role of pyocyanin in Pseudomonas aeruginosa infection. Trends in Molecular Medicine 10(12): 599-606.

Lau, G.W., Ran, H., Kong, F., Hassett, D.J. \& Mavrodi, D. 2004b. Pseudomonas aeruginosa pyocyanin is critical for lung infection in mice. Infection and Immunity 72(7): 4275-4278

Laursen, J.B. \& Nielsen, J. 2004. Phenazine natural products: Biosynthesis, synthetic analogues, and biological activity. Chemical Reviews 104(3): 1663-1686.

Ledderhose, G. 1888. Ueber den blauen Eiter. Langenbecks Arch Klin Chir Ver Dtsch Z Chir 28: 201-230.

Levitch, M.E. \& Rietz,P. 1966. The isolation and characterization of 2-hydroxyphenazine from Pseudomonas aureofaciens. Biochemistry 5(2): 689-692.

Levitch, M. \& Stadtman, E. 1964. A study of the biosynthesis of phenazine-1-carboxylic acid. Archives of Biochemistry and Biophysics 106: 194-199.

Mavrodi, D.V., Parejko, J.A., Mavrodi, O.V., Kwak, Y.S., Weller, D.M., Blankenfeldt, W. \& Thomashow, L.S. 2013. Recent insights into the diversity, frequency and ecological roles of phenazines in fluorescent Pseudomonas spp. Environmental Microbiology 15(3): 675-686.

Mavrodi, D.V., Peever, T.L., Mavrodi, O.V., Parejko, J.A., Raaijmakers, J.M., Lemanceau, P., Mazurier, S., Heide, 
L., Blankenfeldt, W. \& Weller, D.M. 2010. Diversity and evolution of the phenazine biosynthesis pathway. Applied and Environmental Microbiology 76(3): 866-879.

Mavrodi, D.V., Blankenfeldt, W. \& Thomashow, L.S. 2006. Phenazine compounds in fluorescent Pseudomonas sp. biosynthesis and regulation. Annual Review Phytopathology 44: 417-445.

Mavrodi, D.V., Bonsall, R.F., Delaney, S.M., Soule, M.J., Phillips, G. \& Thomashow, L.S. 2001. Functional analysis of gens for biosynthesis of pyocyanin and phenazine-1carboxamide from Pseudomonas aeruginosa PAO1. Journal of Bacteriology 183(21): 6454-6465.

McDonald, M., Mavrodi, D.V., Thomashow, L.S. \& Floss, H.G. 2001. Phenazine biosynthesis in Pseudomonas fluorescens: Branchpoint from the primary shikimate biosynthetic pathway and role of phenazine-1, 6-dicarboxylic acid. Journal of the American Chemical Society 123(38): 9459-9460.

Mentel, M., Ahuja, E.G., Mavrodi, D.V., Breinbauer, R., Thomashow, L.S. \& Blankenfeldt, W. 2009. Of two make one: The biosynthesis of phenazines. Chembiochem. 10(14): 2295-2304.

Parsons, J.F., Song, F., Parsons, L., Calabrese, K., Eisenstein, E. \& Ladner, J.E. 2004a. Structure and function of the phenazine biosynthesis protein PhzF from Pseudomonas fluorescens 2-79. Biochemistry 43(39): 12427-12435.

Parsons, J.F., Calabrese, K., Eisenstein, E. \& Ladner, J.E. 2004b. Structure of the phenazine biosynthesis enzyme PhzG. Acta Crystallographica Section D: Biological Crystallography 60(11): 2110-2113.

Pierson III, L.S. \& Pierson, E.A. 2010. Metabolism and function of phenazines in bacteria: Impacts on the behavior of bacteria in the environment and biotechnological processes. Applied Microbiology and Biotechnology 86(6): 1659-1670.

Pierson, L.S., Gaffney, T., Lam, S. \& Gong, F. 1995. Molecular analysis of gens encoding phenazine biosynthesis in the biological control bacterium Pseudomonas aureofaciens 3084. FEMS Microbiology Letters 134(2-3): 299-307.

Podojil, M. \& Gerber, N.N. 1967. The biosynthesis of 1, 6-phenazinediol 5, 10-dioxide (Iodinin) by Brevibacterium iodinum. Biochemistry 6(9): 2701-2705.

Recinos, D.A., Sekedat, M.D., Hernandez, A., Cohen, T.S., Sakhtah, H., Prince, A.S., Price-Whelan, A. \& Dietrich, L.E. 2012. Redundant phenazine operons in Pseudomonas aeruginosa exhibit environment-dependent expression and differential roles in pathogenicity. Proceedings of the National Academy of Sciences 109(47): 19420-19425.

Reddy, V.M., O’Sullivan, J.F. \& Gangadharam, P.R. 1999. Antimycobacterial activities of riminophenazines. Journal of Antimicrobial Chemotherapy 43(5): 615-623.

Remali, J., Sarmin, N.I.M., Ng, C.L., Tiong, J.J.L., Aizat, W.M., Keong, L.K. \& Zin, N.M. 2017b. Genomic characterization of a new endophytic Streptomyces kebangsaanensis identifies biosynthetic pathway gene clusters for novel phenazine antibiotic production. Peer J. 5: e3738.

Römer,A. \& Herbert, R. 1982. Further observations on the source of nitrogen in phenazine biosynthesis. Z. Naturforsch., Ser. C. 37(11): 1070-1074.

Sarmin, N.I.M., Tan, G.Y.A., Franco, C.M., Edrada-Ebel, R., Latip, J. \& Zin, N.M. 2013. Streptomyces kebangsaanensis sp. nov., an endophytic actinomycete isolated from an ethnomedicinal plant, which produces phenazine-1carboxylic acid. International Journal of Systematic and Evolutionary Microbiology 63(Pt 10): 3733-3738.
Schoental, R. 1941. The nature of the antibacterial agents present in Pseudomonas pyocyanea cultures. British Journal of Experimental Pathology 22(3): 137-147.

Schroeter, J. 1872. Ueber einige durch Bacterien gebildete Pigmente. Beiträge zur Biologie der Pflanzen 1: 109-126.

Selengut, J.D. \& Haft, D.H. 2010. Unexpected abundance of coenzyme F420-dependent enzymes in Mycobacterium tuberculosis and other actinobacteria. Journal of Bacteriology 192(21): 5788-5798.

Smirnov, V.V.\& Kiprianova, E.A. 1990. Bacteria of Pseudomonas genus. Kiev, Ukraine: Naukova Dumka. hlm. 100-111.

Spicer, J.A., Gamage, S.A., Rewcastle, G.W., Finlay, G.J., Bridewell, D.J., Baguley, B.C. \& Denny, W.A. 2000. Bis (phenazine-1-carboxamides): Structure-activity relationships for a new class of dual topoisomerase I/II-directed anticancer drugs. Journal of Medicinal Chemistry 43(7): 1350-1358.

Stewart, A.J., Mistry, P., Dangerfield, W., Bootle, D., Baker, M., Kofler, B., Okiji, S., Baguley, B.C., Denny, W.A. \& Charlton, P.A. 2001. Antitumor activity of XR5944, a novel and potent topoisomerase poison. Anti-cancer Drugs 12(4): 359-367.

Cholo, C.M., Steel, H.C., Fourie, P.B., Germishuizen, W.A., Anderson, R. 2011. Clofazimine: Current status and future prospects. Journal of Antimicrobial Chemotherapy 67(2): 290-298.

Takahashi, I., Takahashi, K.I., Ichimura, M., Morimoto, M., Asano, K., Kawamoto, I., Tomita, F. \& Nakano, H. 1988. Duocarmycin A, a new antitumor antibiotic from Streptomyces. The Journal of Antibiotics 41(12): 1915-1917.

Thomashow, L.S. \& Weller, D.M. 1988. Role of a phenazine antibiotic from Pseudomonas fluorescens in biological control of Gaeumannomyces graminis var. tritici. Journal of Bacteriology 170(8): 3499-3508.

Thomashow, L.S., Weller, D.M., Bonsall, R.F. \& Pierson, L.S. 1990. Production of the antibiotic phenazine-1-carboxylic acid by fluorescent Pseudomonas species in the rhizosphere of wheat. Applied and Environmental Microbiology 56(4): 908-912.

Turner, J.M. \& Messenger, A.J. 1986. Occurrence, biochemistry and physiology of phenazine pigment production. Advances in Microbial Physiology 27: 211-275.

Van't Land, C.W., Mocek, U. \& Floss, H.G. 1993. Biosynthesis of the phenazine antibiotiks, the saphenamycins and esmeraldins, in Streptomyces antibioticus. The Journal of Organic Chemistry 58(24): 6576-6582.

Wang, Y., Luo, Q., Zhang, X. \& Wang, W. 2011. Isolation and purification of a modified phenazine, griseoluteic acid, produced by Streptomyces griseoluteus P510. Research in Microbiology 162(3): 311-319.

Woeng, C.A.T.F., Bloemberg, G.V., van der Bij, A.J., van der Drift, K.M., Schripsema, J., Kroon, B., Scheffer, R.J., Keel, C., Bakker, P.A. \& Tichy, H.V. 1998. Biocontrol by phenazine-1-carboxamide-producing Pseudomonas chlororaphis PCL1391 of tomato root rot caused by Fusarium oxysporum f. sp. radicis-lycopersici. Molecular PlantMicrobe Interactions 11(11): 1069-1077.

Wu, C., Van Wezel, G.P. \& Hae Choi, Y. 2015. Identification of novel endophenaside antibiotics produced by Kitasatospora sp. MBT66. Journal of Antibiotics 68(7): 445-452.

Yun, B.S., Ryoo, I.J., Kim, W.G., Kim, J.P., Koshino, H., Scto, H. \& Yoo, I.D. 1996. Structures of phenazostatins A and $\mathrm{B}$, neuronal cell protecting substances of microbial origin. Tetrahedron Letters 37(47): 8529-8530. 
Juwairiah Remali

Pusat Pengajian Biosains dan Bioteknologi

Fakulti Sains dan Teknologi

Universiti Kebangsaan Malaysia

43600 UKM Bangi, Selangor Darul Ehsan

Malaysia

Noraziah Mohamad Zin*

Pusat Penuaan Sihat dah Kesejahteraan (HCARE)

Fakulti Sains Kesihatan

Universiti Kebangsaan Malaysia

Jalan Raja Muda Abdul Aziz

50300 Kuala Lumpur, Federal Territory

Malaysia

Chyan Leong Ng \& Wan M. Aizat

Institut Biologi Sistem (INBIOSIS)

Universiti Kebangsaan Malaysia

43600 UKM Bangi, Selangor Darul Ehsan

Malaysia
John J.L. Tiong

Pusat Pengajian Farmasi

Universiti Taylor, No. 1, Jalan Taylor's

47500 Subang Jaya, Selangor Darul Ehsan

Malaysia

*Pengarang untuk surat-menyurat; email: noraziah.zin@ukm. edu.my

Diserahkan: 31 Mac 2018

Diterima: 15 November 2018 